\title{
The Effect of Boredom Proneness on Smartphone Addiction and Impulse Purchasing: A Field Study with Young Consumers in Turkey
}

\author{
Ibrahim BOZACI ${ }^{1}$
}

Received: May 01, 2020 Revised: May 10, 2020 Accepted: June 07, 2020

\begin{abstract}
The study seeks to understand the effects of boredom proneness on impulse purchasing and smartphone addiction of young consumers. Moreover, the possible mediating role of smartphone addiction is tested for the effect of boredom proneness on impulse purchasing. Nowadays, the effect of emotions on human behavior is generally accepted, and boredom is one of the important and common problematic feelings or moods at various levels of life due to factors like unemployment, not being able to work in a suitable job, not getting appropriate education matching individual abilities, monotony of tasks, and feeling life is meaningless. Investigating the effect of boredom on specific consumer behavior would increase our knowledge about consumer behavior. For the research, a survey was conducted 313 students from Kirikkale University, Keskin Vocational High School; the data were collected by convenience sampling method. The data were processed through statistical tools like exploratory factor analysis, coefficient alphas, and regression analysis. The results of the study reveal that boredom proneness affects impulse purchasing and smartphone addiction. In addition, it is understood that smartphone addiction plays a mediating role in the effect of boredom proneness on impulse purchasing. These results indicate that boredom can be an important factor affecting certain negative consumer behaviors.
\end{abstract}

Keywords : Boredom Proneness, Impulse Purchase, Smartphone Addiction, Consumer Health

JEL Classification Code: D12, D18, P36, M39

\section{Introduction}

Today, emotions encountered in life can affect human attitudes and behaviors (Weiss \& Cropanzano, 1996, pp. 10-12) and consumers' behavior is affected by individual characteristics (Kim \& Yang, 2020), contextual factors (Phuong \& Dat, 2017), and especially by emotions (Yağc1 \& Çabuk, 2018, pp. 419-455) are both accepted notions. Boredom, which is especially common in people, means a lack of motivation, low physiological arousal (Biolcati et al., 2018), and an insufficient attention capacity. It also causes social, professional and personal problems that must be overcome (Martin et al., 2012). In this research,

${ }^{1}$ First Author and Corresponding Author. Assistant Professor, Department of Marketing and Advertising, Keskin Vocational High School, Kirikkale University, Turkey [Postal Address: Ankara Yolu 7. Km, 71450 Yahşihan / Kirikkale, Turkey]

Email: iborganizer@gmail.com

(c) Copyright: The Author(s)

This is an Open Access article distributed under the terms of the Creative Commons Attribution Non-Commercial License (http://Creativecommons.org/licenses/by-nc/4.0/) which permits unrestricted noncommercial use, distribution, and reproduction in any medium, provided the original work is properly cited. it is suggested that boredom may be related to smartphone addiction and impulse consumption, which are among common problems of today.

Although attempts to reduce boredom through consumption behaviors are evident, research on the relationship between boredom and certain consumer behaviors in marketing science are limited. Within the scope of this research and testing of the theory with primary data, whether impulse purchasing and smartphone addiction are the main consumer behaviors associated with boredom is explored.

\section{Literature Review}

\subsection{The Concept of Boredom}

Boredom is explained as an unpleasant and temporary mood in which an individual feels indifferent and has difficulty focusing on a task. Boredom may arise from several situations such as over-focusing on oneself, being concerned about individual rights such as the right to be happy, not finding anything to do, not receiving any external stimuli, 
not being able to connect with stimulants (knowing the lesson already or finding it meaningless, etc.), experiencing repetitive tasks and a lack of variety, etc. In addition, mood, fatigue, previous experiences and personal interests also affect boredom in a particular situation. Behaviors such as stretching, bending fingers, imagining and scribbling appear as clues to boredom (Conrad, 1997).

Boredom can be expressed as a disturbing and dissatisfying feeling resulting from repetitive, monotonous and prolonged behavior. In particular, there are social processes, activities or situations that causes an individual to experience boredom. This feeling indicates that the individual's current activity or situation is not appealing, is meaningless, and some interesting or meaningful things need to be undertaken. Avoiding boredom is related to social behaviors such as risk-taking and conflict between groups. Therefore, boredom interacts with behavior (Barbalet, 1999). Definitions of boredom emphasized that boredom is related to time, that time loses its value according to the activities performed, and that there is a conscious mental state in the form of being aware of the lack of interest in participating in an activity (Greenson, 1953).

Measurement tools have been developed by scientists to determine boredom in a valid and reliable way. Among these, the Boredom Proneness Scale developed by Farmer and Sundberg (1986) and Short Form of Boredom Proneness Scale developed by Vodanovich et al. (2005) are used in many studies. According to them, boredom proneness consists of insufficient internal and external arousal. While the internal factor is the individual's low ability to identify and process his own feelings and thoughts (Harris, 2000), the external factor is the failure of the individual to satisfy the need for excitement, change and challenge, or their attempts in this direction does not generate satisfaction (Vodanovich \& Kass, 1990). Research has shown that boredom is higher in women in terms of lack of internal stimulants and less in terms of lack of external stimuli (Seib \& Vodanovich, 1998; Studak \& Workman, 2004).

Struk et al. (2017), created an 8-item internally consistent and structurally valid short form of scale by adjusting the style of expression and ensuring consistency between items due to idea that reverse questions in survey forms may cause misinterpretations. Accordingly, boredom consists of components such as finding oneself often in incomplete tasks, difficulty in being entertained, evaluating work as monotonous, not feeling motivated at work, thinking that they should be encouraged to take action and just sitting around not doing anything.

\subsection{Boredom and Consumption}

There has been little research about boredom in the field of consumer behavior, and the relationship between boredom and consumption has mainly been examined as an emotion caused by a particular product or service. For example, while consumers receive services (banking, health, restaurant services, etc.), waiting in line is an inevitable situation (Conrad, 1997). Another example is that nurses often hear patients' complaints about boredom. The boredom experience of psychiatric patients causes the therapeutic potential of the hospital environment to decrease. Therefore, it is recommended that healthcare professionals and managers change the traditional environment of the hospital in a way to eliminate boredom (Binnema, 2004).

In addition to these issues, some of the products with which consumers experience boredom while using are communication tools (such as Facebook), and food and fashion products. Yazdanparast et al. (2015) examined the phenomenon of Facebook boredom among undergraduate students. It concluded that this boredom negatively affected the attitudes towards the social networking site and advertisements on this channel.

Another group of products to which boredom is related is food. Food boredom, which expresses the negative change in the level of liking, causes a decrease in the consumer's interest in the product. As a result, boredom may cause a consumer to pay more for the products they may have eaten long ago, and food variety is recommended in diet programs (Moskowitz, 2000). The feeling of boredom has also been examined in terms of clothing and fashion products. Kwon and Choo (2014) examined the effects of boredom on consumer behaviors such as disposing of products depending upon conditions such as the products becoming obsolescent, not fitting, and changing fashions. Accordingly, variables such as wardrobe management, changes in size, trend, preferences, age, status, design, and new acquisitions encourage the disposal of clothing products. Besides, the relevant research has indicated that clothing products are disposed of because consumers are not seeing them as beautiful, not enjoying them, and getting tired of their design.

One of the goals of marketers is to ensure that consumers do not experience discomfort in the consumption and purchasing of goods and services. Related to this, enjoyable store environments and product diversity that reduces consumers' boredom may influence consumer preferences when choosing among options. Besides this, it is possible to shape consumption behaviors depending on the general boredom that people experience in their lives.

People can see consumption as a method to get rid of the feeling of boredom. Due to the efforts expended to avoid negative emotions, consumption may be beneficial in order to get better conditions or avoid the causes of this situation. In this context, research has shown that consumers who are prone to boredom have more shopping wishes, search for change or diversity, shop to change their moods (Mano, 1999), and buy more fashion products online (Park, 
2015). This study examined the possible effects of boredom proneness on impulse purchasing and smartphone addiction.

\section{Hypothesis Development}

Impulse-based consumer purchases are those that have not been planned completely or partially before entering a store (Berman \& Evans, 2007, pp. 215-216). Impulse purchases are unplanned, occur suddenly, are desire-driven, impulsive and the result of an internal psychological condition to purchase a product, and are characterized by little attention being paid to the results of the purchase (Piron, 1991; Rook, 1987, Rook \& Fisher, 1995; Rook \& Gardner, 1993; Rook \& Hoch, 1985).

A great deal of research has been conducted on impulse purchasing behavior. It is evident that impulse purchasing is effected by mood (Rook, 1987) as well as many other factors like low price, disposable income (Berman \& Evans, 2007, pp. 215-216), self-perception, suppression of emotions, delay of instant satisfaction (Kacen \& Lee, 2002, p. 163), shop environment or atmosphere, salespeople, product features (product category, product variety, etc.), promotion activities, age, low perceived risk, high materialism, individualistic culture, general impulsivity (Ünsalan, 2016), and social norms (Rook \& Fisher, 1995).

Impulse consumption can especially be affected by strong emotions (Aruna \& Santhi, 2015; Baun \& GroeppelKlein, 2003). For example, when people are in a positive mood (experiencing fun, etc.), they can be more generous and rewarding toward themselves (Beatty \& Ferrell, 1998; Dittmar et al., 1996; Gardner \& Rook, 1988). On the other hand, although the effects of negative emotions on consumers are not as clear as positive emotions, it is possible to think that impulse consumption can be engaged in to reduce negative emotions, such as depression, or to improve mood (Glen \& DeMoss, 1990). For example, when people are stressed or get depressed, they go to the kitchen more often and buy products such as clothing and cosmetics more frequently. In brief, it is understood that consumption behaviors can be engaged in for therapeutic purposes (Luomala, 2002) or to manage negative moods (Luomala, 1998).

In addition to this, research has shown that boredom leads to problematic eating behaviors (excessive calories, etc.) (Abramson \& Stinson, 1977; Crockett et al., 2015; Koball et al., 2012; Moynihan et al., 2015; Walfish \& Brown, 2009), drinking behaviors (Biolcati et al., 2018), participation in special event entertainment (children's games during school holidays, fashion shows, etc.) (Galloway, 2002; Sit et al., 2006), engagement in leisure activities such as listening to music (Mitchell et al., 2007) and paying a higher price for products (Dal Mas \& Witmann, 2017); all of this supports the idea that boredom can affect impulse purchasing.
Research also exists in the marketing literature that supports the idea that boredom can directly affect impulse purchases (Dittmar \& Drury, 2000; Gasiorowska, 2011; Geuens et al., 2004). In the in-depth interviews by Sundström et al. (2019), it was found that when young consumers were bored, they reacted more to marketing stimuli (price, easy access, free delivery, etc.) to break the monotony. In addition, in the experimental research by Moynihan et al. (2017), a relationship between boredom and impulsiveness was revealed. Based on the research findings and related discussions, the first hypothesis is as follows:

\section{H1: Boredom proneness affects impulse purchasing.}

Technological improvements may lead new behavioral problems like social media/network (Choi, 2018; Choi et al. 2019) and smartphone addiction, which affect daily life negatively. In the use of smart phones, which is common today and consumes a significant part of the day, people experience problems related to control. As in other countries, research has shown that smartphone addiction among young people is quite common in Turkey. Accordingly, people feel deprived when they are not using their smartphones, have difficulty controlling their smartphone use, and have difficulties in their lives due to their smartphone use (Fidan, 2016; Kuyucu, 2017; Noyan et al., 2015).

Research has also shown that negative emotions like depression, anxiety (Kardefelt-Winther, 2014; Long et al., 2016) and loneliness (Aktaş \& Yılmaz, 2017; Mert \& Özdemir, 2018) are associated with increased problematic internet and smartphone use. In addition, besides the studies that have shown that boredom affects young people's addiction behaviors such as smoking, excessive alcohol use and gambling (Biolcati et al., 2016; Hunter \& Csikszentmihalyi, 2003; Mercer \& Eastwood, 2010; Ziervogel et al., 1997), there are studies that have shown that boredom affects problematic or excessive Internet use (Biolcati et al., 2018; Lin et al., 2009; Wegmann et al., 2018) and problematic smartphone usage (Elhai et al., 2018; Elhai et al., 2019; Matic et al., 2015; Wolniewicz et al., 2019). Therefore, the idea that boredom affects smartphone addiction is put forward within the scope of this research and the following hypothesis is formulated:

$\mathrm{H} 2$ : Boredom proneness affects smartphone addiction.

Additionally, this research questions whether smartphone addiction plays a mediating role in the effect of boredom on impulse consumption. It is possible that because smartphones consume a significant part of the day and mental resources, smartphone addiction is in conflict with the ability to realize impulse consumption, and it can decrease impulse 
consumption. However, there is no scientific evidence regarding this possible effect. Accordingly, the third hypothesis of the research is:

H3: Smartphone addiction plays a mediating role in the effect of boredom proneness on impulse consumption.

\section{Research Methods and Materials}

The primary goal of this research is to test the possible effects of boredom on impulse purchasing and smartphone addiction on a sample in Turkey. In addition, whether smartphone addiction plays a mediating role in the effect of boredom proneness on internal consumption is also examined.

In the research, a survey was conducted with 313 students of Kirikkale University Keskin Vocational High School; the data were collected by convenience sampling method between the dates of 16.12.2019 and 27.12.2019. In the development of the research measurement tool, previouslyconducted scientific research was employed to measure the variables - to measure boredom proneness, Struk et al.'s (2017) study was used; to measure impulse purchasing, Sneath et al.'s (2019) and Rook \& Hoch's (1985) studies were used; and to measure smartphone addiction, LopezFernandez's (2017) and Kwon et al.'s (2013) studies were employed. The items for boredom proneness have been translated into Turkish, and the items for impulse purchasing and smartphone addiction have been adapted from the aforementioned studies.

\subsection{General Features of the Participants}

Three hundred and thirteen vocational high school students participated in the research. While $67.1 \%$ of the 313 participants were 20 year-old and older, $32.6 \%$ were under 20. In terms of gender, $86.9 \%$ of the participants were women. In general, the participants consisted of students, young people and people who have similar characteristics and are without a regular income (see Table 1).

Table 1: Characteristics of the Participants

\begin{tabular}{|l|c|c|}
\hline \multicolumn{1}{|c|}{ Gender } & Quantity & Valid Percentage \\
\hline Female & 272 & 86.9 \\
\hline Male & 41 & 13.1 \\
\hline Monthly Income \\
\hline 500 TL and below & 141 & 55.1 \\
\hline 500 TL and above & 115 & 44.9 \\
\hline Age \\
\hline $17-19$ & 102 & 32.7 \\
\hline 20 and above & 210 & 67.3 \\
\hline
\end{tabular}

\subsection{Factor and Reliability Analysis}

Due to the fact that the research measurement tool is largely adapted, exploratory factor analysis was performed for structural validity of the survey instrument. In addition, coefficient alphas were calculated to determine the reliability of the item groups prepared for the purpose of measuring the research variables. According to the reliability analysis conducted for the statements prepared to determine the boredom proneness, the coefficient alpha was found to be 0.70 and sufficient. According to the exploratory factor analysis performed for this variable, the $\mathrm{KMO}$ coefficient was determined to be 0.704 , and it was understood that the data were suitable for factor analysis. Five items with factor loads higher than 0.5 were included in the analysis and these explained $42.75 \%$ of the total variance (see Table 2).

According to the factor analysis conducted for the items prepared to measure impulse purchasing, it was determined that the KMO coefficient was 0.740 , and the related 4 items explained $61.946 \%$ of the total variance. The reliability value of the question group was calculated as 0.740 (see Table 3).

According to the factor analysis conducted for the items prepared to determine smartphone addiction, the KMO coefficient was determined as 0.829 . The prepared items were allocated to two factors explaining $55.502 \%$ of the total variance, and the factors were named "deprivation/ dominance" and "problematic use/results" respectively according to the purposes for the preparation of the questions. The reliability coefficients of the question groups that made up the addiction dimensions were determined to be sufficient (see Table 4).

Table 2: Factor Analysis I/ Boredom Proneness

\begin{tabular}{|l|c|}
\hline & $\begin{array}{c}\text { Factor } \\
\text { Loadings }\end{array}$ \\
\hline $\begin{array}{l}\text { In most situations, it is hard for me to find } \\
\text { something to do or see to keep me interested. }\end{array}$ & .755 \\
\hline $\begin{array}{l}\text { Much of the time, I just sit around doing } \\
\text { nothing. }\end{array}$ & .693 \\
\hline $\begin{array}{l}\text { Many things I have to do are repetitive and } \\
\text { monotonous. }\end{array}$ & .635 \\
\hline $\begin{array}{l}\text { I often find myself at a "loose end", not } \\
\text { knowing what to do. }\end{array}$ & .590 \\
\hline I don't feel motivated by most things that I do. & .579 \\
\hline $\begin{array}{l}\text { Total Explained Variance: } 42.75 \% ; \text { Alpha: } 0.704 ; \text { Average: } \\
2.57 .\end{array}$ \\
\hline The items have been translated from the original Turkish. \\
\hline
\end{tabular}


Table 3: Factor Analysis II/ Impulse Purchasing

\begin{tabular}{|c|c|}
\hline & $\begin{array}{l}\text { Factor } \\
\text { Loadings }\end{array}$ \\
\hline I buy products that I don't really need. & .879 \\
\hline $\begin{array}{l}\text { I purchase thing that I wouldn't normally } \\
\text { purchase. }\end{array}$ & .878 \\
\hline $\begin{array}{l}\text { I purchase things that I don't know why I } \\
\text { bought them after buying them. }\end{array}$ & .782 \\
\hline I buy things that I don't plan to purchase. & .567 \\
\hline \multicolumn{2}{|c|}{$\begin{array}{l}\text { Total Explained Variance: } 61.946 \% \text {; Alpha: } 0.741 \text {; } \\
\text { Average: } 2.33 .\end{array}$} \\
\hline \multicolumn{2}{|c|}{ The items have been translated from the original Turkish. } \\
\hline
\end{tabular}

Table 4: Factor Analysis III/ Smartphone Addiction

\begin{tabular}{|c|c|c|}
\hline & $\begin{array}{l}\text { Deprivation } \\
\text { Idominance }\end{array}$ & $\begin{array}{l}\text { Problematic } \\
\text { use/results }\end{array}$ \\
\hline $\begin{array}{l}\text { I can't bear the absence of } \\
\text { my smartphone. }\end{array}$ & .831 & \\
\hline $\begin{array}{l}\text { I am impatient and nervous } \\
\text { when I don't hold my } \\
\text { smartphone. }\end{array}$ & .766 & \\
\hline $\begin{array}{l}\text { My smartphone is on my } \\
\text { mind even when I'm not } \\
\text { using it. }\end{array}$ & .740 & \\
\hline $\begin{array}{l}\text { I don't stop using my } \\
\text { smartphone even if my daily } \\
\text { life is negatively affected. }\end{array}$ & .716 & \\
\hline \multicolumn{3}{|c|}{ Explained Variance: 41.543; Alpha: 0.814; Average: 2.58.} \\
\hline $\begin{array}{l}\text { I miss my planned work } \\
\text { because I use smartphone. }\end{array}$ & & .747 \\
\hline $\begin{array}{l}\text { I am having difficulty } \\
\text { because of using } \\
\text { smartphone while trying to } \\
\text { concentrate in class, doing } \\
\text { homework or working. }\end{array}$ & & .739 \\
\hline $\begin{array}{l}\text { I feel pain in my wrists and } \\
\text { at the back of my neck } \\
\text { while using a smartphone. }\end{array}$ & & .631 \\
\hline $\begin{array}{l}\text { I use my smartphone for } \\
\text { longer than I had planned } \\
\text { to. }\end{array}$ & & .594 \\
\hline $\begin{array}{l}\text { People around me say I use } \\
\text { my smartphone a lot. }\end{array}$ & & .530 \\
\hline \multicolumn{3}{|c|}{$\begin{array}{l}\text { Explained Variance: 13.959. Total Explained Variance: } \\
\text { 55.50. Alpha: } 0.751 \text {. Average: } 2.60 .\end{array}$} \\
\hline
\end{tabular}

\subsection{Testing the Hypotheses}

Multiple regression analyses were performed to test the research hypotheses. First, according to the model it was found that boredom proneness affects impulse consumption (standard $\beta=0,258$ ) significantly; H1, "Boredom proneness affects impulse purchasing", was thus supported (see Table 5).

Secondly, it has been determined that boredom proneness affects the problematic use/problematic results dimension $(\beta$ : $0.307)$ and the dominance/deprivation dimension ( $\beta: 0.328)$ of smartphone addiction. Thus, H2, "Boredom proneness affects smartphone addiction", was supported (see Table 6).

Finally, regression analysis was carried out to test the third hypothesis. Boredom proneness and smartphone addiction dimensions were included in the same model as variables likely to affect impulse purchasing. In order to conclude that there is a mediating role besides the independent variable affecting the dependent variable and the mediating variable, the effect of the independent variable on the dependent variable should disappear or decrease when the independent variable and the mediating variable are combined (Baron \& Kenny, 1986, p. 1176). According to the analysis carried out in this framework, when smartphone addiction occurred, the effect of boredom proneness on impulse purchasing disappears (Standard $\beta$ decreased from 0,258 to 0,091). So, a mediating role of smartphone addiction was evidenced. Hence, H3, "Smartphone addiction plays a mediating role in the effect of boredom proneness on impulse purchasing", was supported (see Table 7).

Table 5: Regression Analysis I

First Model: Effect of boredom proneness on impulse purchasing

\begin{tabular}{|l|c|c|}
\hline & $\beta$ & Sig. \\
\hline Boredom proneness & $0.258^{*}$ & 0,000 \\
\hline$R^{2}$ : 0,066; F: 122,000; Dubwin Watson: 1,723; sig. 0.000 \\
\hline
\end{tabular}

Table 6: Regression Analysis II

\begin{tabular}{|l|c|c|}
\hline $\begin{array}{l}\text { Second Model I: Effect of } \\
\text { problematic use/results dimension of smartphone addiction }\end{array}$ \\
\hline & $\beta$ & Sig. \\
\hline Boredom proneness & $0.307^{*}$ & 0,000 \\
\hline R2: 0.094; F: 30,404; Dubwin Watson: 2.061 ; sig. 0.000. \\
\hline $\begin{array}{l}\text { Second Model II: Effect of boredom proneness on } \\
\text { dominance/deprivation dimension of smartphone addiction }\end{array}$ \\
\hline Boredom proneness & $0.328^{*}$ & 0,000 \\
\hline R: 0,108; F: 37,368; Dubwin Watson: 1.927 ; sig. 0.000 \\
\hline
\end{tabular}


Table 7: Regression Analysis III

\begin{tabular}{|l|c|c|}
\hline \multicolumn{3}{|l|}{ Third Model: Mediating role of smartphone addiction } \\
\hline & $\beta$ & Sig. \\
\hline Boredom proneness & 0,091 & 0,094 \\
\hline $\begin{array}{l}\text { Smartphone Addiction: Deprivation/ } \\
\text { dominance }\end{array}$ & $0.138^{*}$ & 0,021 \\
\hline $\begin{array}{l}\text { Smartphone Addiction: Problematic } \\
\text { use/results }\end{array}$ & $0.397^{*}$ & 0,000 \\
\hline$R^{2}: 0.271 ;$ F: 35,765; Dubwin Watson: 1,747; sig. 0,000 \\
\hline
\end{tabular}

\section{Results and Discussion}

As a result of the research, the conclusion that boredom proneness affects impulse consumption is similar to the results of studies in the marketing literature that show that consumers become involved in impulse-related consumption behaviors (snacking, eating, drinking, having fun, etc.) in order to correct negative emotions and moods (Abramson \& Stinson, 1977; Biolcati et al., 2018; Crockett et al., 2015; Galloway, 2002; Koball et al., 2012; Luomala, 1998, 2002; Glen \& DeMoss, 1990; Mitchell et al., 2007; Moynihan et al., 2015; Rook, 1987; Sit et al., 2006; Sundström et al., 2019; Walfish \& Brown, 2009; Virvilaite et al., 2011). In addition, this finding is similar to the results of research that concludes that boredom affects impulse purchase (Dittmar \& Drury, 2000; Gasiorowska, 2011; Geuens et al., 2004). Therefore, it is understood that boredom proneness affects the impulse purchasing of the young consumers of our sample in the Kirikkale province of Turkey.

Moreover, the conclusion that boredom proneness affects smartphone addiction is also similar to that of studies in the related literature, which show that boredom is connected to problematic Internet use (Biolcati et al., 2018; Lin et al., 2009; Wegmann et al., 2018) and problematic smartphone use (Elhai et al., 2018; Elhai et al., 2019; Matic et al., 2015; Wolniewicz. 2019). Therefore, the idea that boredom proneness is a variable that affects smartphone addiction among young people is supported in this study.

In addition, when smartphone addiction and boredom proneness are combined in the same model, the mediating effect of smartphone addiction with respect to the effect of boredom proneness on impulse purchasing is the original result of this research. Therefore, it can be asserted that when boredom proneness is high, impulse consumption is lower due to a high smartphone addiction level. This shows that the use of smartphones at a higher problematic level causes a variation in the importance of factors affecting impulse purchasing. In other words, smartphone addiction may be thought of as a substitute for impulse consumption in terms of reducing the effect of boredom.

\section{Conclusions}

In this research dealing with the effects of boredom on a specific consumer behavior, it is evident that boredom proneness is related to an increase in smartphone addiction and impulse purchasing. This result supports the general idea that boredom, as a negative emotion or mood, may be a major contributor to certain consumer behaviors. In addition, the fact that smartphone addiction reduces the effect of boredom on impulse purchasing is another result of this research.

The results demonstrate the need to manage boredom, which is one of the most important problems facing young people today as it is one of the triggering variables for smartphone addiction. Therefore, it can be suggested that young people should be educated in areas appropriate to their abilities and interests, so that they can comprehend the meaning of the behaviors or tasks in which they are engaged and be focused on and motivated in their activities in order to reduce their problematic use of smartphones and increase their ability to make more conscious and fulfilling purchases. It is possible for parents and educational institutions, managers and employees to take precautions in reducing boredom.

As with any research, this research has its limitations. Conducting the research via a survey method necessitates that the participants' answers to the items in the survey be considered truthful. In addition, the realization of the research using vocational high school student participants, a young and narrow customer group, restricts the generalization of the research results. However, it is thought that the research findings are useful in order to test the claims put forth in this research on a specific group of customers. Conducting similar research with a larger sample will contribute to our understanding of the subject.

\section{References}

Abramson, E. E., \& Stinson, S. G. (1977). Boredom and eating in obese and non-obese individuals. Addictive Behaviors, 2(4), 181-185, https://doi.org/10.1016/0306-4603(77)90015-6.

Aktaş, H., \& Yılmaz, N. (2017). Smartphone addiction in terms of the elements of loneliness and shyness of university youth. International Journal of Social Sciences and Education Research, 3(1), 85-100, https://doi.org/10.24289/ijsser.283590.

Aruna, S., \& Santhi, P. (2015). Impulse purchase behavior among generation-Y. Journal of Marketing Management, 14(1), 21-38, https://ssrn.com/abstract=2805619.

Barbalet, J. M. (1999). Boredom and social meaning. The British Journal of Sociology, 50(4), 631-646, https://doi.org/10.1111/ j.1468-4446.1999.00631.x.

Baron, R. M., \& Kenny, D. A. (1986). The moderator-mediator variable distinction in social psychological research: 
conceptual, strategic, and statistical considerations, Journal of Personality and Social Psychology, 51(6), 1173-1182.

Baun, D., \& Groeppel-Klein, A. (2003). Joy and surprise as guides to a better understanding of impulse buying behaviour. European Advances in Consumer Research, 6, 290-299.

Beatty, S. E., \& Ferrell, M. E. (1998). Impulse buying: modeline its precursors. Journal of Retailing, 74(2), 169-191, https://doi. org/10.1016/S0022-4359(99)80092-X.

Berman, B., \& Evans, J.R. (2007). Retail Management A Strategic Approach (10th ed.), New Jersey: Pearson Education.

Binnema, D. (2004). Interrelations of psychiatric patient experiences of boredom and mental health. Issues in Mental Health Nursing, 25(8), 833-842, https://doi.org/10.1080/01612840490506400.

Biolcati, R., Mancini, G., \& Trombini, E. (2018). Proneness to boredom and risk behaviors during adolescents' free time. Psychological Reports, 121(2), 303-323, https://doi. org/10.1177/0033294117724447.

Biolcati, R., Passini, S., \& Mancini, G. (2016). I cannot stand the boredom. Binge drinking expectancies in adolescence. Addictive Behaviors Reports, 3, 70-76, https://doi.org/10.1016/j. abrep.2016.05.001.

Choi, Y. (2018). Narcissism and social media addiction in workplace. Journal of Asian Finance, Economics and Business, 5(2), 95-104, https://doi.org/10.13106/jafeb.2018.vo15.no2.95.

Choi, Y., Chu, K., \& Choi, E. J. (2019). Social Network Services Addiction in the Workplace. The Journal of Asian Finance, Economics and Business, 6(1), 249-259, http://doi. org/10.13106/jafeb.2019.vol6.no1.249.

Conrad, P. (1997). It's boring: Notes on the meanings of boredom in everyday life. Qualitative Sociology, 20(4), 465-475, https:// doi.org/10.1023/A:1024747820595.

Crockett, A. C., Myhre, S. K., \& Rokke, P. D. (2015). Boredom proneness and emotion regulation predict emotional eating. Journal of Health Psychology, 20(5), 670-680, https://doi. org/10.1177/1359105315573439.

Dal Mas, D. E., \& Wittmann, B. C. (2017). Avoiding boredom: Caudate and insula activity reflects boredom-elicited purchase bias. Cortex, 92, 57-69, https://doi.org/10.1016/j. cortex.2017.03.008.

Dittmar, H., \& Drury, J. (2000). Self-image Is it in the bag? A qualitative comparison between "ordinary" and "excessive" consumers. Journal of Economic Psychology, 21(2), 109-142, https://doi.org/10.1016/S0167-4870(99)00039-2.

Dittmar, H., Beattie, J., \& Friese, S. (1996). Objects, decisions considerations and self - image in men's and women's impulse purchases. Acta Psychologica, 93, 187-206.

Elhai, J. D., Rozgonjuk, D., Alghraibeh, A. M., \& Yang, H. (2019). Disrupted daily activities from interruptive smartphone notifications: Relations with depression and anxiety severity and the mediating role of boredom proneness. Social Science Computer Review, 2019, 1-18, https://doi. org/10.1177/0894439319858008.
Elhai, J. D., Vasquez, J. K., Lustgarten, S. D., Levine, J. C., \& Hall, B. J. (2018). Proneness to boredom mediates relationships between problematic smartphone use with depression and anxiety severity. Social Science Computer Review, 36(6), 707720, https://doi.org/10.1177/0894439317741087.

Farmer, R., \& Sundberg, N. D. (1986). Boredom proneness: The development and correlates of a new scale. Journal of Personality Assessment, 50, 4-17, https://doi.org/10.1207/ s15327752jpa5001_2.

Fidan, H. (2016). Development and validation of the mobile addiction scale: The components model approach. Addicta: The Turkish Journal on Addictions, 3, 433-469, https://doi. org/10.15805/addicta.2016.3.0118.

Galloway, G. (2002). Psychographic segmentation of park visitor markets: evidence for the utility of sensation seeking. Tourism Management, 23(6), 581-596, https://doi.org/10.1016/S02615177(02)00025-0.

Gardner, M.P., \& Rook, D. W. (1988). Effects of impulse purchases on consumers' affective states. Advances in Consumer Research, 15, 127-130.

Gasiorowska, A. (2011). Gender as a moderator of temperamental causes of impulse buying tendency. Journal of Customer Behaviour, 10(2), 119-142, https://doi. org/10.1362/147539211X589546.

Geuens, M., Vantomme, D., \& Brengman, M. (2004). Developing a typology of airport shoppers. Tourism Management, 25(5), 615-622, https://doi.org/10.1016/j.tourman.2003.07.003.

Greenson, R. (1953). On boredom. Journal of American Psychoanalytic Association, 1, 7-21, https://doi.org/10.1177/0 00306515300100102.

Harris, M. B. (2000). Correlates and characteristics of boredom proneness and boredom. Journal of Applied Social Psychology, 30(3), 576-598, https://doi.org/10.1111/j.1559-1816.2000. tb02497.x.

Hunter, J.P., \& Csikszentmihalyi, M. (2003). The positive psychology of interested adolescents. Journal of Youth and Adolescence, 32, 27-35, https://doi.org/10.1023/A:1021028306392.

Kacen, J. J., \& Lee, J. A. (2002). The influence of culture on consumer impulsive buying behavior. Journal of Consumer Psychology, 12(2), 163-176, https://doi.org/10.1207/ S15327663JCP1202_08.

Kardefelt-Winther, D. (2014). A conceptual and methodological critique of internet addiction research: Towards a model of compensatory internet use. Computers in Human Behavior, 31, 351-354, https://doi.org/10.1016/j.chb.2013.10.059.

Kim, Y. E., \& Yang, H. C. (2020). The effects of perceived satisfaction level of high-involvement product choice attribute of Millennial generation on repurchase intention: Moderating effect of gender difference. Journal of Asian Finance, Economics and Business, 7(1), 131-140, https://doi. org/10.13106/jafeb.2020.vol7.no1.131.

Koball, A. M., Meers, M. R., Storfer-Isser, A., Domoff, S. E., \& Musher-Eizenman, D. R. (2012). Eating when bored: Revision 
of the emotional eating scale with a focus on boredom. Health Psychology, 31(4), 521-524, https://doi.org/10.1037/a0025893.

Kuyucu, M. (2017). Use of smart phone and problematic of smart phone addiction in young people: "Smart phone (colic)" university youth. Global Media Journal TR Edition, 7(14), 328-359.

Kwon, H. J., \& Choo, H. J. (2014). The effect of boredom on clothing disposal behavior. In 2014 Global Fashion Management Conference in London, Global Alliance of Marketing \& Management Associations, 286-290.

Kwon, M., Kim, D. J., Cho, H., \& Yang, S. (2013). The smartphone addiction scale: development and validation of a short version for adolescents. PloS One, 8(12), e83558, 10.1371/journal. pone. 0083558 .

Lin, C. H., Lin, S. L., \& Wu, C. P. (2009). The effects of parental monitoring and leisure boredom on adolescents' internet addiction. Adolescence, 44(176), 993.

Long, J., Liu, T. Q., Liao, Y. H., Qi, C., He, H. Y., Chen, S. B., \& Billieux, J. (2016). Prevalence and correlates of problematic smartphone use in a large random sample of Chinese undergraduates. BMC Psychiatry, 16, 408, https://doi. org/10.1186/s12888-016-1083-3.

Lopez-Fernandez, O. (2017). Short version of the Smartphone Addiction Scale adapted to Spanish and French: Towards a cross-cultural research in problematic mobile phone use. Addictive Behaviors, 64, 275-280, https://doi.org/10.1016/j. addbeh.2015.11.013.

Luomala, H. T. (1998). A mood-alleviative perspective on selfgift behaviours: Stimulating consumer behaviour theory development. Journal of Marketing Management, 14(1-3), 109-132, https://doi.org/10.1362/026725798784959318.

Luomala, H. T. (2002). An empirical analysis of the practices and therapeutic power of mood-alleviative consumption in Finland. Psychology \& Marketing, 19(10), 813-836, https://doi. org/10.1002/mar.10039.

Mano, H. (1999). The influence of pre-existing negative affect on store purchase intentions. Journal of Retailing, 75(2), 149-173, https://doi.org/10.1016/S0022-4359(99)00002-0.

Martin, M., Sadlo, G., \& Stew, G. (2012). Rethinking occupational deprivation and boredom. Journal of Occupational Science, 19(1), 54-61, https://doi.org/10.1080/14427591.2011.640210.

Matic, A., Pielot, M., \& Oliver, N. (2015). Boredomcomputer interaction: Boredom proneness and the use of smartphone. International Joint Conference on Pervasive and Ubiquitous Computing, ACM, Osaka, Japan, https://doi. org/10.1145/2750858.2807530.

Mercer, K. B., \& Eastwood, J. D. (2010). Is boredom associated with problem gambling behaviour? It depends on what you mean by 'boredom'. International Gambling Studies, 10(1), 91-104, https://doi.org/10.1080/14459791003754414.

Mert,A., \& Özdemir, G. (2018). The effects of sense of lonesomeness to the smart phone addiction. OPUS International Journal of
Society Researches, 8(1), 88-107, https://doi.org/10.26466/ opus.382285.

Glen, M. D., \& DeMoss, M. (1990). Self-gifts: Phenomenoiogical insights from four contexts. Journal of Consumer Research, 17(December), 322-332, https://doi.org/10.1086/208560.

Mitchell, L. A., MacDonald, R. A. R., Knussen, C., \& Serpell, M. G. (2007). A survey investigation of the effects of music listening on chronic pain. Psychology of Music, 35(1), 37-57, https://doi.org/10.1177/0305735607068887.

Moskowitz, H. R. (2000). Engineering out food boredom: a product development approach that combines home use tests and timepreference analysis. Food Quality and Preference, 11(6), 445456, https://doi.org/10.1016/S0950-3293(00)00016-1.

Moynihan, A. B., Igou, E. R., \& van Tilburg, W. A. (2017). Boredom increases impulsiveness. Social Psychology, 48, 1-56, https:// doi.org/10.1027/1864-9335/a000317.

Moynihan, A. B., Van Tilburg, W. A., Igou, E. R., Wisman, A., Donnelly, A. E., \& Mulcaire, J. B. (2015). Eaten up by boredom: consuming food to escape awareness of the bored self. Frontiers in Psychology, 6, 1-10, https://doi.org/10.3389/ fpsyg.2015.00369.

Noyan, C. O., Enez D.A., Nurmedov, S., Y1lmaz, O., \& Dilbaz, N. (2015). Validity and reliability of the Turkish version of the Smartphone Addiction Scale-Short Version among university students. Anatolian Journal of Psychiatry, 16, 73-81, http:// dx.doi.org/10.5455/apd.176101.

Park, H. J. (2015). The influences of boredom proneness, public self-consciousness, and dressing style on internet shopping. The Research Journal of the Costume Culture, 23(5), 876-893, https://doi.org/10.7741/rjcc.2015.23.5.876.

Phuong, N. N. D., \& Dat, N. T. (2017). The effect of country-oforigin on customer purchase intention: A study of functional products in Vietnam. Journal of Asian Finance, Economics and Business, 4(3), 75-83, http://dx.doi.org/10.13106/jafeb.2017. vol4.no3.75.

Piron, F. (1991). Defining impulse purchasing. Advances in Consumer Research, 18, 509-514, https://www.acrwebsite.org/ volumes/7206.

Rook, D. W. (1987). The buying impulse. Journal of Consumer Research, 14(2), 189-199, https://doi.org/10.1086/209105.

Rook, D. W., \& Fisher, R. J. (1995). Normative influences on impulsive buying behavior. Journal of Consumer Research, 22(3), 305-313, https://doi.org/10.1086/209452.

Rook, D.W. (1987). The buying impulse. Journal of Consumer Research, 14(2), 189-99, https://doi.org/10.1086/209105.

Rook, D.W., \& Hoch, S.J. (1985). Consuming impulses. Advances in Consumer Research, 12, 23-27.

Rook, D.W., \& Gardner, M. (1993). In the mood: Impulse buying's affective antecedents. Research in Consumer Behavior. 6, 1-28.

Seib, H.M., \& Vodanovich, S.J. (1998) Cognitive correlates of boredom proneness: the role of private self-consciousness and 
absorption. Journal of Psychology, 132, 642-653, https://doi. org/10.1080/00223989809599295.

Sit, J., Johnson-Morgan, M., \& Summers, J. (2006). Understanding consumer responses to special event entertainment (SEE) in shopping centers: a conceptual model. International Conference on Business and Information (BAI 2006), Singapore.

Sneath, J. Z., Lacey, R., \& Kennett-Hensel, P. A. (2009). Coping with a natural disaster: Losses, emotions, and impulsive and compulsive buying. Marketing Letters, 20(1), 45-60, https:// doi.org/10.1007/s11002-008-9049-y.

Struk, A. A., Carriere, J. S., Cheyne, J. A., \& Danckert, J. (2017). A short boredom proneness scale: Development and psychometric properties. Assessment, 24(3), 346-359, https:// doi.org/10.1177/1073191115609996.

Studak, C.M., \& Workman, J.E. (2004) Fashion groups, gender, and boredom proneness. International Journal of Consumer Studies, 28(1), 66-74, https://doi.org/10.1111/j.14706431.2004.00335.x.

Sundström, M., Hjelm-Lidholm, S., \& Radon, A. (2019). Clicking the boredom away- Exploring impulse fashion buying behavior online. Journal of Retailing and Consumer Services, 47, 150156, https://doi.org/10.1016/j.jretconser.2018.11.006.

Ünsalan, M. (2016). Stimulating factors of impulse buying behavior: A literature review. Gazi University Journal of Faculty of Economics and Administrative Sciences, 18(2), 572-593, https://dergipark.org.tr/tr/pub/gaziuiibfd/issue/28287/300477.

Virvilaite, R., Saladienè, V., \& Žvinklyte, J. (2011). The impact of external and internal stimuli on impulsive purchasing. Economics and Management, 16, 1329-1336.

Vodanovich, S. J., \& Kass, S. J. (1990). A factor analytic study of the boredom proneness scale. Journal of Personality Assessment, 55(1-2), 115-123, https://doi.org/10.1080/00223891.1990.967 4051 .
Vodanovich, S. J., Wallace, J. C., \& Kass, S. J. (2005). A confirmatory approach to the factor structure of the Boredom Proneness Scale: Evidence for a two-factor short form. Journal of Personality Assessment, 85(3), 295-303, https://doi. org/10.1207/s15327752jpa8503_05.

Walfish, S., \& Brown, T. A. (2009). Self-assessed emotional factors contributing to increased weight in presurgical male bariatric patients. Bariatric Nursing and Surgical Patient Care, 4(1), 4952, https://doi.org/10.1381/0960892042583897.

Wegmann, E., Ostendorf, S., \& Brand, M. (2018). Is it beneficial to use Internet-communication for escaping from boredom? Boredom proneness interacts with cue-induced craving and avoidance expectancies in explaining symptoms of Internetcommunication disorder. PloS One, 13(4), 1-18, https://doi. org/10.1371/journal.pone.0195742.

Weiss, H. M., \& Cropanzano, R. (1996). Affective events theory: A theoretical discussion of the structure, causes and consequences of affective experiences at work, Research in Organizational Behavior, 18, 1-74.

Wolniewicz, C. A., Rozgonjuk, D., \& Elhai, J. D. (2019). Boredom proneness and fear of missing out mediate relations between depression and anxiety with problematic smartphone use. Human Behavior and Emerging Technologies, 2019, 1-10, https://doi.org/10.1002/hbe2.159.

Yağc1, M.İ., \& Çabuk, S., (2018), Marketing Theories (2nd ed.), İstanbul, Turkey: Mediacat.

Yazdanparast, A., Joseph, M., \& Qureshi, A. (2015). An investigation of Facebook boredom phenomenon among college students. Young Consumers, 16(4), 468-480.

Ziervogel, C. F., Ahmed, N., Flisher, A. J., \& Roberston, B. A. (1997). Alcohol misuse in South African male adolescents: A qualitative investigation. International Quarterly of Community Health Education, 17, 25-41, https://doi.org/10.2190/43AD41TW-V20W-71QB. 